\title{
Distributive Justice and the Relief of Household Debt*
}

\author{
GOVIND PERSAD \\ Bioethics, Johns Hopkins University
}

$\mathbf{S}^{\mathrm{s}}$ INCE the financial crisis, household debt has been widely discussed among social scientists, policy makers, and activists. Many have questioned the increasing levels of debt households are required to take on in order to purchase housing, vehicles, and access to higher education. Proposals for assisting households in debt have included "rolling jubilees," where collectives purchase household debts from creditors at a discount; the provision of various goods and services-such as higher education and housing-at public expense rather than via debt financing; interest rate regulation and limitations on access to credit; and the forgiveness of household debts. Theorists of distributive justice, however, have remained largely outside this lively discussion.

This article aims to fill that gap by offering a normative examination of the distributive justice issues presented by proposals to relieve household debt or protect households from overindebtedness. In Section I, I examine two goals at which debt relief proposals aim: remedying disadvantage and stabilizing expectations. In Sections II and III, I assess how various debt relief strategies serve those goals, with Section II focussing on strategies for relieving existing debts, while Section III examines strategies for addressing future debts.

My focus in what follows will be on how debt and its relief affect the substantive distribution of goods among members of society, and on whether and when debt constitutes a substantive distributive injustice. Debt can also constitute a procedural injustice, as when someone is deceived into assuming or paying a legally invalid debt by an unscrupulous lender or debt collector. Frequently, debt taken on in procedurally unjust ways also has substantively unjust distributive effects, as recently demonstrated by Wells Fargo's deception of poor and ethnic minority customers into opening accounts that led to overdraft fees and debt collection. The empirical connection between procedurally and substantively

"I am grateful to attendees at the Finance and Social Justice Conference at the University of Bayreuth for helpful discussion at an earlier presentation of these ideas, to Marco Meyer for his assistance in organizing papers from the conference, and to Kate Padgett Walsh and Mark Davidson for their generosity in providing source materials. I am also grateful to Robert Goodin and to two anonymous referees for this journal for their detailed comments on earlier drafts of this article, and to Kristen Miller and Anne Gelling for their further assistance. 
unjust debts means that certain procedural requirements, such as "cooling off" periods or prohibitions on lending to minors, can help to realize substantive justice. But procedural and substantive injustice are conceptually separable: a debt could have a procedurally impeccable history but still impose substantively unjust burdens, or could be procedurally unjust without being substantively burdensome.

Any project that, like this one, normatively assesses specific social institutions and proposals, such as debt and debt relief, must consider the fact that institutions take on different tasks in the goal of remedying injustice. ${ }^{1}$ One way of dividing labor among institutions would make the sole aim of regulation of private debt, including debt relief, the improvement of overall societal productivity without attention to distributive justice, while some other institution, such as the tax system, works to justly distribute the fruits of social productivity. ${ }^{2}$ Another arrangement might regard each institution as aiming to relieve injustice with respect to the specific benefit or burden it distributes, but not to relieve injustice more generally across society. My approach, in contrast, takes the position that debt relief proposals and other regulation of private debt ought at the very least not set back distributive justice across society, and could also work to achieve justice more broadly. However, it also recognizes that debt relief efforts cannot be the only or primary means of achieving distributive justice.

\section{TWO GOALS OF DEBT RELIEF: REMEDYING DISADVANTAGE AND STABILIZING EXPECTATIONS}

Debt relief proposals typically aim at at least one of two goals: remedying absolute disadvantage (that is, addressing debts that plunge individuals into, or keep them in, poverty) and stabilizing individual economic expectations (that is, addressing debts that expose individuals to a decline in their economic position). ${ }^{3}$ Some proposals serve both ends. However, remedying disadvantage and stabilizing expectations can come apart. One relevant example involves the proper definition of "overindebtedness." Some definitions of the term come closer to characterizing it as debt-induced disadvantage, others to characterizing it as debt-induced disruption of expectations. The former category includes definitions of overindebtedness in terms of permanent arrears, loss of a liquidity buffer, or reduction to a minimum standard of living, while the latter includes definitions that consider "borrowers over-indebted if they need to reduce expenditures

\footnotetext{
${ }^{1}$ This concerns the division of labor among different institutions, rather than the division of labor between institutions and individuals. On the latter question, see, for instance, Thomas Nagel, Equality and Partiality (New York: Oxford University Press, 1991), ch. 6.

${ }^{2} \mathrm{~A}$ thesis of this sort is defended in Louis Kaplow and Steven Shavell, "Why the legal system is less efficient than the income tax in redistributing income," Journal of Legal Studies, 23 (1994), 667-81, but criticized in Zachary Liscow, "Reducing inequality on the cheap: when legal rule design should incorporate equity as well as efficiency," Yale Law Journal, 123 (2013), 2478-510.

${ }^{3}$ These two goals are distinguished in Robert E. Goodin, "Stabilizing expectations: the role of earnings-related benefits in social welfare policy," Ethics, 100 (1990), 539-42.
} 
below the level they are accustomed to" or regard any sacrifice by debtors as a sign of overindebtedness. ${ }^{4}$ Selecting the proper definition of overindebtedness involves taking a position on which end-remedying disadvantage or stabilizing expectations-debt relief should serve.

In some cases, the same policies can serve both to stabilize expectations and to remedy disadvantage. This can happen, for instance, if stabilizing expectations for the more advantaged produces economic benefits for the disadvantaged. One such argument contends that assisting households in keeping up their spending patterns will tend to counteract recessions and therefore allow for economic growth. ${ }^{5}$ If this growth in turn benefits the disadvantaged, the goals of stabilizing expectations and remedying disadvantage would be aligned.

Stabilizing expectations and remedying disadvantage, however, can and do also conflict. In such cases, which aim should take priority? Many debt relief proposals-in particular mortgage relief and the relief of large consumer debtsdo better at stabilizing expectations than at remedying disadvantage. Stabilizing expectations, however, is a less normatively pressing goal than remedying disadvantage. While loss of economic position may be psychologically upsetting and disruptive to individuals' plans, it is-even when it stems from bad brute luck-simply a less serious problem than absolute disadvantage. ${ }^{6}$ As one point of support for this claim, the persistently poor would typically be happy to trade places with the downwardly mobile whose expectations have been disrupted, while the reverse is not true.

In the next two sections, I turn to the evaluation of several proposals for household debt relief, both those that target already incurred debt and those that target debt yet to be incurred. These proposals include debt forgiveness, mitigation of debt burdens, public provision as an alternative to debt financing, limitations on access to credit, and encouragement of lower-debt lifestyles.

\section{ADDRESSING EXISTING DEBT}

As I describe potential ways of addressing debt, it is important to remember that many of the policies under discussion have second-order and third-order implications that require careful empirical analysis. Many policies that directly affect debtors and creditors have indirect effects on other actors and on the economy more generally, which will in turn have consequences for debtors, for the stabilization of expectations, and for the least advantaged. As an example, regulatory arrangements such as interest rate caps can lead to the regulated

\footnotetext{
${ }^{4}$ For a review of these definitions, see Jessica Schicks, "The definition and causes of microfinance over-indebtedness: a customer protection point of view," Oxford Development Studies, 41 (2013), S95-S116 at pp. S98-9.

${ }^{5}$ Lisa Herzog, "What could be wrong with a mortgage? Private debt markets from a perspective of structural injustice," Journal of Political Philosophy, 25 (2017), 428-9 and n. 87.

${ }^{6}$ Govind Persad, "Downward mobility and Rawlsian justice," Philosophical Studies (forthcoming); Govind Persad, "On H. M. Oliver's 'Established Expectations and American Economic Policies,” Ethics, 125 (2015), 831-32.
} 
actors remaining in the market and producing better results, but they can also lead to exit from the market or to the production of black markets. I have neither the space nor the expertise to investigate these empirical issues in depth, but hope that attention to these issues stimulates future empirical work. $^{7}$

\section{A. Debt Abolition}

One way of addressing the burden of existing debt is to forgive it entirely. Some activist groups have argued for the complete abolition of debt as a social practice. Others have proposed "jubilee" arrangements, in which some or all debts are periodically forgiven. In real-world practice, some bankruptcy laws allow for the complete or partial forgiveness of debt.

Even under non-ideal circumstances where many debts were taken on unjustly, the complete abolition of debt as a social practice is normatively difficult to justify, in the same way as the abolition of other social practices, such as contracts or deadlines, would be. No matter what one's view of justice, some debts-just like some contracts and deadlines-will threaten the achievement of justice. But other debts, contracts, or deadlines will further the achievement of justice. As the activist Strike Debt movement (revealingly) concedes, abolition would "liberate debtors at random," promote justice. ${ }^{9}$

Abolishing debt wholesale or at random would abolish debts that impose few burdens, while doing nothing to help many needy individuals who are not in debt. Some examples of debt abolition could even worsen needy individuals' situation (as might happen, for instance, with the abolition of child support debts). It makes far more sense to eliminate only those debts whose removal would enable the realization of a more just society, and to pursue steps other than debt relief toward achieving justice. ${ }^{10}$

\footnotetext{
${ }^{7}$ Some of these empirical issues are explored on a level accessible to the layperson in Adair Turner, Between Debt and the Devil: Money, Credit, and Fixing Global Finance (Princeton: Princeton University Press, 2016); and in Atif Mian and Amir Sufi, House of Debt: How They (and You) Caused the Great Recession, and How We Can Prevent It from Happening Again (Chicago: University of Chicago Press, 2015).

${ }^{8}$ Donna Schaper, "What's next in faith-based community organizing: a rolling jubilee," Tikkun, 28 (2013), 36-8, at p. 37 (quoting the Strike Debt Manifesto).

${ }^{9}$ On this point, see Seth Ackerman's questions-which ultimately go unanswered-to Strike Debt activist Andrew Ross in "Strike Debt and rolling jubilee: the debate," Dissent (Nov. 13, 2012), $<$ https://www.dissentmagazine.org/online_articles/strike-debt-the-debate $>$; "is all debt illegitimate, or just some debt? Should only some debts be cancelled, or should all of them be-in which case, wouldn't we also lose most of our savings? Should there be a permanent end to the existence of debt; if so, what kind of system should replace it?".

${ }^{10}$ Thomas Piketty makes a similar point in a recent exchange with David Graeber, "Soak the rich: an exchange on capital, debt, and the future," The Baffler, 25 (2014), 148-54, at p. 153, observing that "the last creditors are not necessarily the ones who should be made to pay," as would be the case under debt abolition, and arguing instead for "the proposal that a progressive tax be imposed on wealth."
} 


\section{B. TARGETED FORGIVENESS}

Which debts impede justice, of course, will depend on one's account of justice. An account of justice that emphasizes remedying disadvantage might initially appear to favor forgiving debts that were incurred in order to obtain basic needs. ${ }^{11}$ However, some such debts involve no disadvantage: it is difficult to believe that a comfortably well-off person cannot consent to use a credit card to purchase necessities such as food. ${ }^{12}$ Furthermore, disadvantaged people are sometimes trapped in poverty by debts that were originally incurred in order to purchase goods that might appear frivolous to outside observers. ${ }^{13}$ Even if these debts are less unjust than those that are both immiserating and incurred to access basic needs, ignoring them altogether would arguably constitute wrongful abandonment of the imprudent. ${ }^{14}$

Additionally, while a forgiveness proposal targeting disadvantaged people who incur debts to obtain basic needs would still be an improvement over the status quo, it would do nothing for individuals whose access to basic needs is impeded by obstacles such as low income or ill health, rather than by debt. This suggests that debt forgiveness grounded in the goal of remedying disadvantage must be paired with efforts to provide comparable assistance to poor nondebtors. These might include broad assistance to the least advantaged, whether through a universal basic income, efforts to achieve full employment, or access to resources such as housing, education, and health care. Even if a given debt regime is highly unjust as things currently stand, relieving general poverty and inequality will frequently do more both for justice in general and for the justice of the debt regime than a narrow focus on relieving debts.

An emphasis on remedying disadvantage also requires considering how debt relief affects creditors. A debt should not be relieved when doing so would leave an individual creditor severely disadvantaged, such as the case of child support debts discussed above. Even if debt relief would not directly subject an individual creditor to disadvantage, it can indirectly conflict with remedying disadvantage if it consumes public resources that could otherwise have reduced disadvantage. One article notes that income tax debts-which, if paid, would have produced revenues used to support public programs-are involved in nearly one-fifth of

\footnotetext{
${ }^{11}$ See Alex Gourevitch, "Debt, freedom, and inequality," Philosophical Topics, 40 (2012), 135-51, at pp. 146-7; Mark A. Davidson, "Is liberalism drowning in debt? The impact of private debt on individual liberty," Journal of Poverty and Social Justice, 19 (2011), 263-75, at p. 265.

${ }^{12}$ I therefore reject Davidson's categorical claim that "the choice to assume debt for the purchase of necessities is either non-consensual, or lacking moral traction"; "Is liberalism drowning in debt?", p. 265.

${ }^{13}$ See Abhijit Banerjee and Esther Duflo, Poor Economics: A Radical Rethinking of the Way to Fight Global Poverty (New York: PublicAffairs, 2012), pp. 35-9.

${ }^{14}$ For two different explanations of why abandoning the imprudent is wrong, see Elizabeth $S$. Anderson, "What is the point of equality?", Ethics, 109 (1999), 287-337; and Shlomi Segall, "In solidarity with the imprudent: a defense of luck egalitarianism," Social Theory and Practice, 33 (2007), 177-98.
} 
bankruptcies. ${ }^{15}$ Others note that nonprofit and charitable creditors collect debts in order to serve others who need their aid: a bankruptcy that leaves debts to a public hospital unpaid reduces the funds the hospital has available to care for ill or impoverished people. ${ }^{16}$

\section{BANKRUPTCY LAW}

In practice, much debt relief occurs through bankruptcy law rather than through either debt abolition or an arrangement that forgives debt for the least advantaged or for debts incurred to secure basic needs. This presents the normative question of how bankruptcy law should treat individuals, and whether it should allow debtors to maintain their past consumption patterns. Remedying disadvantage recommends a revisionary approach to bankruptcy law: rather than providing bankruptcy exemptions that shield better-off debtors' assets from creditors, bankruptcy law should focus on assisting the least advantaged. Bankruptcy scholar William Vukowich criticizes exemption laws on the basis that

they tend to perpetuate our economic class structure. Those who have are allowed to keep; those who do not are given nothing. This class perpetuation is most vivid when courts and commentators urge an application of the exemption laws that allows a debtor to "maintain a standard of living reasonably consistent with his occupation and previous history." 17

A similar point is made by an advocate for debtors, who notes that

exemption law obviously favors the rich and the middle-class because it allows people to keep a large percentage of what they have acquired in terms of property, reinforcing the status quo. On the other hand, if one is poor and has not acquired many assets, then the exemptions scheme also maintains the status quo. They still have nothing. ${ }^{18}$

From the perspective of remedying disadvantage, bankruptcy law ought to aim at ensuring that debtors are not disadvantaged, but need not maintain debtors' prior economic position, particularly when doing so might come at the expense of the disadvantaged. This perspective will therefore look warily on the suggestion that bankruptcy law shift the risk of mortgages or student loans to taxpayers in general. ${ }^{19}$ While mortgages and student loans should be designed to give borrowers an escape-through bankruptcy or foreclosure-before they drop into

\footnotetext{
${ }^{15}$ Michelle Arnopol Cecil, "Crumbs for Oliver Twist: resolving the conflict between tax and support claims in bankruptcy," Virginia Tax Review, 20 (2000), 719-75, at p. 743.

${ }^{16}$ Melissa B. Jacoby and Elizabeth Warren, "Beyond hospital misbehavior: an alternative account of medical-related financial distress," Northwestern Law Review, 100 (2006), 525-84.

${ }^{17}$ William T. Vukowich, "Debtors' exemption rights under the Bankruptcy Reform Act," North Carolina Law Review, 58 (1980), 769-814, at p. 770.

${ }^{18}$ Nathalie Martin, "Poverty, culture and the Bankruptcy Code: narratives from the money law clinic," Clinical Law Review, 12 (2005), 203-41, at p. 232.

${ }^{19}$ See Herzog, "What could be wrong with a mortgage?”, p. 428.
} 
poverty, some of their risk may permissibly fall on borrowers. However, because bankruptcy law generally involves distribution only between creditor and debtor, an approach that emphasizes remedying disadvantage may have little to say about cases where a bankruptcy simply transfers private resources from a wealthy creditor to a non-disadvantaged debtor with few effects on society at large.

In contrast, as the above discussion of bankruptcy law's tendency to protect the status quo suggests, an account of distributive justice that emphasizes the importance of stabilizing expectations will be much friendlier to current debt relief arrangements in bankruptcy law, including those which assist wealthy and middle-class debtors rather than the disadvantaged. One article observes that, " $[t]$ he current bankruptcy statutes implicitly ... decree that part of the fresh start is some preservation of current status when the debtor enters bankruptcy." ${ }^{20} \mathrm{~A}$ broader survey makes the case that debtors in bankruptcy are entitled to have their previously more advantaged status preserved:

Even the monetary data, which show a substantial number of the debtors in poverty, contain evidence of the debtors' once-middle-class financial lives: their educational attainments, their formerly higher incomes, and their substantial rates of homeownership hark back to an earlier time of more middle-class financial, as well as social, status.... The debtors in our sample include accountants and computer engineers, doctors and dentists, clerks and executives, salesclerks and librarians, teachers and entrepreneurs. They are middle-class folks who are supposed to be gathering around the barbecues on the patios outside their three-bedroom, two-bath houses, not waiting to be examined under oath by their creditors in austere federal courthouses. ${ }^{21}$

The authors also assert that these debtors" "bankruptcies show not that they have left the middle class but that they are in bankruptcy to hang on to their fragile position in the middle class." 22

Rather than attending solely to substantive questions concerning the effects of debts on disadvantage or on the stability of expectations, bankruptcy law may also attend to procedural questions concerning how debts were acquired. This could be because procedural questions are inherently important to the legitimacy of debt, as with debts that are taken on absent appropriate consent, or because certain types of debts tend to produce disadvantage. Interestingly, current legal arrangements make it easier to disclaim debts taken on for non-essentials than to disclaim debts taken on for essentials. Rather than prohibiting loans for certain types of goods or to certain groups, it would make more sense to focus on the background phenomenon of disadvantage.

\footnotetext{
${ }^{20}$ Elizabeth Warren, "Reducing bankruptcy protection for consumers: a response," Georgetown Law Review, 72 (1983), 1333-57, at p. 1356.

${ }^{21}$ Teresa A. Sullivan, Elizabeth Warren, and Jay Lawrence Westbrook, The Fragile Middle Class: Americans in Debt (New Haven: Yale University Press, 2000), p. 6.

${ }^{22}$ Ibid., p. 73.
} 


\section{Mitigation}

An alternative to easing the burden of debt by eliminating or forgiving debt is to adopt policies that mitigate that burden. One way of mitigating debt is via an economic policy that is more debtor-friendly-one that reduces the burden of debt via inflation. Inflation does not eliminate debt altogether but, rather, improves the position of current debtors at the expense of their creditors by raising nominal incomes without similarly increasing existing debts. From the perspective of remedying disadvantage, inflation-based approaches to debt can be attractive because the most disadvantaged individuals-whether or not they are debtors-are typically not creditors. Furthermore, a more debtor-friendly policy can be designed in a way that also reduces unemployment, because certain steps to prevent unemployment also tend to produce inflation. ${ }^{23}$ Since unemployment is a major form of disadvantage in its own right and also produces other forms of disadvantage, promoting full employment would remedy disadvantage.

However, debtor-friendly economic policies might raise concerns from the perspective of stabilizing expectations, because inflation, even though it could help debtors maintain their economic position, will tend to disrupt the expectations of creditors and cause their economic position to decline. This concern is buttressed by the fact that changes in monetary policy are typically most effective when they are unanticipated, since economically rational creditors will price anticipated inflation into the terms of loans. These unanticipated measures can be contrary to the goal of providing stable future expectations to assist individuals in planning their lives. However, whether they are contrary to remedying disadvantage is an empirical question that involves weighing the economic costs for the least advantaged that result from disrupted expectations against the economic benefits they realize from policy change.

Other ways of mitigating the burden of debt would make debt repayment a smaller part of individuals' net economic position by raising individuals' income, or would offset the burdens of debt repayment by decreasing the costs of obtaining goods such as housing, food, and transportation. Such efforts would assist both individuals who have moved up economically but face the risk of dropping down due to debt and non-debtors who are currently at the bottom of the economic ladder. In contrast, debt relief proposals only assist the former group. Hence, efforts to boost income or make consumption cheaper are likely to secure support from those who endorse remedying disadvantage, without immediately raising concerns from the perspective of stabilizing expectations.

A final way of mitigating the burden of debt is to offer partial debt forgiveness conditioned on proof of disadvantage. This strategy is exemplified by incomebased debt repayment plans, which are typically offered by governments or by

\footnotetext{
${ }^{23}$ See Jacqueline Best, "Rethinking central bank accountability in uncertain times," Ethics and International Affairs, 30 (2016), 215-32, at p. 219; and also Mark R. Reiff, On Unemployment (New York: Palgrave, 2015), vol. 1, pp. 28-33.
} 
nonprofit creditors such as universities, and which base individuals' debt payments on their current income. Income-based repayment plans are potentially consistent both with remedying disadvantage and with stabilizing expectations, since they focus the greatest assistance on individuals who are most economically disadvantaged, but do not lead to fluctuations in economic position-they behave analogously to a predictable progressive tax on debtors' income.

\section{ADDRESSING FUTURE DEBT}

The field of options widens when we consider whether and how to address problems that debts might impose on individuals who are not yet indebted, but might become indebted in future. The core issue here is prevention: how can we ensure that individuals do not become excessively indebted? As I observe above, the literature on overindebtedness provides neither easy answers nor clear definitions; but potential solutions involve reducing individuals' out-of-pocket costs for goods, reducing the rate at which debt accumulates, regulating the assumption of debt, and discouraging an ethos of consumption.

\section{A. Public Provision and Public Financing}

Alex Gourevitch argues that "the most desirable alternative to debt-financed consumption is the unconditional public provision of basic goods like housing, education, and medical care." 24 The perspective of remedying disadvantage provides at least two good reasons to doubt this claim. First, the public can-and frequently should-ensure access to basic goods without providing those goods directly, by ensuring that everyone has sufficient resources to purchase those goods in markets. Secondly, there is an ambiguity in Gourevitch's understanding of basic goods: while some basic amount of housing, education, and medical care are essential goods, most houses, educational institutions, and medical procedures also have non-essential aspects.

Turn first to the question of how best to provide certain goods. Gourevitch runs together two questions: (1) whether access to some goods should be guaranteed via public financing, and (2) whether the state should directly provide those goods. ${ }^{25}$ State provision is one way of guaranteeing access to a good. Another way of guaranteeing access involves publicly financing access to the good by providing individuals with resources that they can in turn use to purchase that good. Public financing can involve cash transfers, such as a universal basic income, or good-specific vouchers, such as tax credits to purchase private health insurance or scholarships to attend universities. Both public financing and direct public provision serve to prevent individuals from incurring debt. At most,

\footnotetext{
${ }^{24}$ Gourevitch, "Debt, freedom, and inequality," p. 139; for a similar suggestion, see Nancy Holmstrom, "Debt forgiveness: who owes whom for what?", Tikkun, 30 (2015), 41-2, at p. 42.

${ }^{25}$ The two questions are distinguished and examined in Liam Murphy and Thomas Nagel, "Taxes, redistribution, and public provision," Philosophy and Public Affairs, 30 (2001), 53-71.
} 
Gourevitch's argument supports the idea that there should be publicly financed access to basic goods, not that the goods should additionally be publicly provided. $^{26}$

We then reach the second issue, regarding the ambiguity of basic goods. While it makes sense for the public to finance basic goods, there is no obvious public interest in financing private consumption. Gourevitch's view is ambiguous between two alternatives: (1) that all housing, higher education, and medical care are basic goods, and (2) that a decent minimum of housing, higher education, and medical care are basic goods. The first alternative is implausibly broad-while a mansion does provide a roof over one's head, it provides many other private benefits that are not basic or essential. To assert that " $[\mathrm{h}]$ ousing, health care, and education ... are indispensable social goods, not consumer commodities" ${ }^{27}$ is an oversimplification-the more complex truth is that while some aspects of housing, health care, and education are indispensable social goods, other aspects of these goods are indeed consumer commodities. The second, decent-minimum alternative is more attractive, but it points toward a tiered model where people are guaranteed a decent minimum and then could supplement this minimum with additional spending.

Once everyone is guaranteed a decent minimum (which could be done by providing the disadvantaged a subsidy from the public purse in order to access a decent minimum of goods like housing, education, and health care), there is no obvious reason-from the perspective of remedying disadvantage-to prohibit arrangements that require better-off individuals who seek housing, education, or health care to finance access to those goods through private debt. Gourevitch worries that debt financing, and self-financing more generally, unjustly limits individuals" "choice of careers and work opportunities." 28 However, if only individuals who end up better off are required to bear the costs of consumption (as with income-based repayment programs), then individuals will not be foreclosed from pursuing their preferred careers, but will simply face trade-offs.

It is true that the higher self-financing burdens that fall on those earning a higher income will affect their choice of careers; however, progressive taxation to fund publicly financed education would do the same. Arrangements that require

\footnotetext{
${ }^{26}$ There are advantages to having certain goods not only publicly financed, but also provided by the state. Public provision can be important for civic solidarity, as with goods like public schools that are collectively consumed, and can ensure optimal access to nonexcludable goods with positive externalities, such as national defense, that individuals would otherwise underpurchase for themselves. However, there is no compelling reason why goods-even essential goods-that are excludable and not collectively consumed should be publicly provided as opposed to merely publicly financed. This is contrary to Paul A. Hampton, "Power without the king: the debt strike as credible threat," Tikkun, 30 (2015), 31-4, at p. 32, who suggests that not only education and health care, but also food and housing "can and should be provided outside market mechanisms and thus outside the grasp of odious debts." Public financing uses a market mechanism to guarantee access to food and housing without allowing for odious debts.

${ }^{27}$ Ross, "Strike Debt and rolling jubilee."

${ }^{28}$ Gourevitch, "Debt, freedom, and inequality," p. 148.
} 
students who end up better off to self-finance their education through incomebased repayment are importantly different from those that require worse-off students to self-finance their education through up-front debt that may not be forgiven. Unlike up-front financing, income-based repayment does not subject any student to a trade-off that others do not face, nor does it constrain students' opportunities based on their initial wealth. And, while income-based repayment does have the potential to affect initial choice of occupation, the same is true for any system of income taxation. Both income-based repayment and income taxation are simply an instance of the more general phenomenon of economic trade-offs factoring into and sometimes limiting our choices. The presence of economic trade-offs in our everyday lives is not obviously destructive to autonomy.

While having the better off finance their own education, housing, or health care is permissible, it is not required. It can be acceptable to publicly provide these goods at no charge to anyone, even the better off. Whether the better off should receive free or subsidized access to a good, or should instead have to pay for it out of pocket or through debt financing, largely rests on the empirical effects of each policy. These effects include the costs of subsidizing the better off or providing them the good directly; the costs and social burdens of gatekeeping and meanstesting arrangements that restrict access to publicly provided goods; and the positive social externalities of increasing consumption of the good. The answer can frequently vary depending on the good at issue: in many countries, the better off pay for food and housing, but receive free or subsidized access to health care. A more controversial effect to consider is the political consequences of offering subsidies or public provision to the better off. Some argue-exemplified by the slogan "programs for the poor are poor programs"- that offering these benefits to the better off helps to secure their political support for these programs. ${ }^{29}$ However, viewed through an ethical rather than a realpolitik lens, this justification for providing benefits threatens to shade into objectionably allowing the better off to determine the structure of social programs through unjust behavior. $^{30}$

Another incentive effect that raises similar issues is the use of subsidies or public provision to encourage certain career choices. As an example, the United States currently has an undersupply of primary care physicians compared to specialist physicians, which limits access to affordable first-line medical care. Some suggest that this undersupply results from having medical school be debt financed, since medical school debt influences trainees to enter higher-paying specialist positions; they argue for making medical school free or establishing

\footnotetext{
${ }^{29}$ See, for instance, Jonah B. Gelbach and Lant H. Pritchett, "Indicator targeting in a political economy: leakier can be better," Journal of Policy Reform, 4 (2001), 113-45.

${ }^{30}$ See G. A. Cohen, Rescuing Justice and Equality (Cambridge, MA: Harvard University Press, 2009), ch. 1. The distinction between "principled" and "baldly pragmatic" rationales for stabilizing expectations is discussed in Goodin, "Stabilizing expectations," p. 533.
} 
loan-forgiveness programs. However, some might complain that publicly providing or even more heavily subsidizing access to lucrative medical training unjustly caters to individuals who are making unfair demands: instead, medical students should consider their own ethical obligations when making career choices.

I have argued that the goal of remedying disadvantage does not support the general case for public provision of goods that Gourevitch advances, because public provision is frequently not the best way of remedying disadvantage. In contrast, whether an approach based on stabilizing expectations supports public provision will largely be an empirical question. Individuals of all economic ranks would benefit from the stability associated with public provision of goods. The empirical question would be whether the disruption of individual expectations required to publicly provide these goods outweighs the gain in stability.

\section{B. CRedit AND Interest Rate Regulations}

Other ways of preventing the rise of future debt would make debts more difficult to incur by limiting access to credit, or make incurred debts less onerous by setting limits on interest rates. Tighter standards for credit eligibility would prevent people from going into debt, since fewer creditors would be willing to lend. The same might be true for limits on interest rates, which might shut the riskiest debtors out of credit markets if creditors are unwilling to lend to them even at the highest allowable rate.

From the perspective of stabilizing expectations, tighter standards for credit look attractive. Limiting access to credit could help to prevent the disappointment of expectations, by ensuring that individuals do not become accustomed to a debt-financed standard of living that cannot be sustained in the long term. ${ }^{31}$ If individuals cannot climb as high by borrowing, they will have less far to fall. Further, while credit limitations may prevent disadvantaged people from obtaining credit in a bid to improve their economic position, they also allow people who already have some resources to maintain their preferred standard of living without having to compete with others who have borrowed to reach that standard, and without themselves having to borrow. Richard Arneson offers an argument of this sort:

Market activity has an inevitable gambling dimension, and there will be winners and losers of the gambles. Some people strongly desire economic security. Thurow has remarked that everybody supports the free market-for the other fellow. For oneself a more secure, cartel-like arrangement is preferred. These preferences can be collectively self-defeating if each person loses more from the cartel-seeking behavior of others than she gains from her own similarly

\footnotetext{
${ }^{31}$ Elizabeth Warren and Amelia Warren Tyagi, The Two-Income Trap: Why Middle-Class Parents Are Going Broke (New York: Basic Books, 2004), p. 152; Sean Hannon Williams, "“Sticky expectations: responses to persistent over-optimism in marriage, employment contracts, and credit card use," Notre Dame Law Review, 84 (2009), 733-91, at pp. 780-1.
} 
motivated behavior. But in the general case this need not be so. Suppose most people come to prefer a diminution in economic gambling opportunities. They would prefer not to gamble themselves and not to be leapfrogged by others who choose to gamble. ${ }^{32}$

Though Arneson's argument is made in the context of more general restrictions on markets, it applies well to the case of credit markets. If some individuals dislike the danger of dropping in relative or absolute economic position, they will benefit from a general policy of limiting access to credit that prevents others from disturbing their accustomed position by borrowing money in order to compete.

In contrast, the perspective of remedying disadvantage could provide a basis for rejecting rationales like Arneson's. Arneson concedes that "hard fairness issues ... arise in deciding to what extent state policy should cater to some people's desires for security and relative equality at the expense of other people's desires for entrepreneurial risk taking." ${ }^{33}$ The case for protecting the risk-averse becomes much weaker when the entrepreneurial risk taking is being pursued by the disadvantaged rather than by the wealthy. Some disadvantaged people may want access to credit as a way of escaping disadvantage-by obtaining credit, they can build their human capital or obtain other forms of capital such as equipment. By then using this capital, they can repay the debt and improve their economic position. Microfinance proposals in developing countries are built on just this sort of logic. While ensuring that individuals are not being deceived by unscrupulous lenders and have some protection from downside risks is warranted, more extensive limitations on credit access can favor the risk-averse at the expense of the least advantaged. Loans for small amounts of money, in particular, are unlikely to produce large-scale disruptions in markets, and can help the least advantaged improve their economic position.

The risk of excessive indebtedness and default is only one type of financial risk. Another is the risk of permanent economic disadvantage due to insufficient access to credit. Jennifer Rubenstein argues that there is no normatively compelling reason to regard apparently acute needs (such as economic loss due to default) as more important than chronic ones (such as ongoing poverty). ${ }^{34}$ Rubenstein makes the case that greater emphasis on acute needs typically reflects normatively indefensible underpinnings: in particular, a conflation of usual states of affairs with normatively acceptable ones. While ongoing poverty is less surprising or unusual than a sudden default, it is at least as worthy of ethical attention. If access

\footnotetext{
${ }^{32}$ Richard J. Arneson, "Comment on Krouse and McPherson," Ethics, 97 (1986), 139-45, at p. 143.

${ }^{33}$ Ibid.; see also Herzog, "What could be wrong with a mortgage?", p. 423, "For some, [debt] markets create new opportunities, for others, one small mistake or misfortune can lead into a spiral of debt that closes off numerous opportunities."

${ }^{34}$ Jennifer Rubenstein, "Distribution and emergency," Journal of Political Philosophy, 15 (2007), 296-320.
} 
to credit can help counteract persistent poverty, it may be worth providing even if it comes with some risk.

Some reasons for limiting access to credit, however, do fit well with the goal of remedying disadvantage. One such reason is the prevention of bidding wars over scarce positional goods. Under some circumstances, access to credit may encourage bidding wars and weaken individuals' ability to credibly signal a price above which they are unwilling to go. For instance, when housing is absolutely scarce, greater access to credit may simply permit landlords or sellers to raise prices even higher. ${ }^{35}$ Even when these bidding wars do not directly produce disadvantage, they may consume resources that could instead be used to counteract disadvantage. While concerns about bidding wars may not justify a general limitation on access to credit, they could justify targeted limitations on certain types of private debt that are frequently used to obtain absolutely scarce goods. Targeting these limitations appropriately would involve identifying which goods are purely or primarily positional. ${ }^{36}$

Another reason for regulating credit access, and in particular for capping interest rates, is to improve the bargaining power of poor debtors. Herzog points out that certain markets for credit, particularly markets used by poor debtors, are distorted in favor of creditors because of information deficits and debtors' lack of other options. ${ }^{37}$ Where markets depart from ideal conditions, as they frequently do, regulations-including interest rate regulations-could in principle help to improve the position of the disadvantaged with minimal losses in efficiency. Marek Hudon and Arvind Ashta argue that, in light of market imperfections, transactions in microcredit markets produce a "joint social surplus outside of the fair terms of distribution associated (even) with perfect competition," which raises not only the question of whether debtors gain on the whole from these transactions, but also of whether they receive a fair share of this surplus. ${ }^{38}$

While Hudon and Ashta's focus is voluntary efforts by microcredit lenders to set fair interest rates, externally imposed interest rate caps can also improve the bargaining power of the poor under non-ideal market circumstances. As Alan Wertheimer observes,

\footnotetext{
${ }^{35}$ See the example in Alan Wertheimer, "Book review: Terrance McConnell, Inalienable Rights," Law and Philosophy, 20 (2001), 541-51, at p. 544. Elizabeth Warren and Amelia Warren Tyagi discuss the bidding war for housing that middle-class families in the USA face in The Two-Income Trap, ch. 2 .

${ }^{36}$ On this topic, see Harry Brighouse and Adam Swift, "Equality, priority, and positional goods," Ethics, 116 (2006), 471-97; see also Robert H. Frank, Luxury Fever: Weighing the Cost of Excess (New York: Free Press, 1999).

${ }^{37}$ Herzog, "What could be wrong with a mortgage?", pp. 422-3; see also Marek Hudon and Arvind Ashta, "Fairness and microcredit interest rates: from Rawlsian principles of justice to the distribution of the bargaining range," Business Ethics: A European Review, 22 (2013), 277-91, at p. 281.

${ }^{38}$ Hudon and Ashta, "Fairness and microcredit interest rates," pp. 281, 285.
} 
If $B$ has the right to work for less than $\$ 6.00$ per hour, it is possible that $C$ will be able to get B to work for $\$ 5.00$ per hour. But if we treat B's right to work for at least $\$ 6.00$ per hour as inalienable, then C may offer B at least that amount. ${ }^{39}$

A maximum interest rate may have similar effects to a minimum wage. Of course, whether a given maximum rate actually improves the situation of poor debtors by enabling them to access credit on better terms, as opposed to simply excluding them from credit markets or driving them into black markets, is an empirical question that depends on the minimum interest rate (that is, the reservation price) that creditors are willing to accept, ${ }^{40}$ but it is plausible, given the imperfections of credit markets, that interest rate caps do assist disadvantaged debtors in at least some cases.

A third reason to limit access to credit involves the possibility of debt-driven "internalities," where debtors harm their own long-term prospects, or externalities, where debtors harm the prospects of others. Examples of the former would be a prohibition on debts that allow garnishment of social security or of other benefits that individuals stand to receive in the far future. Given individuals' lack of knowledge regarding their future situation, it might be good policy to prevent imprudence. Meanwhile, one example of an externality would be debts incurred by parents that interfere with their ability to provide their children with fair equality of opportunity.

\section{ENCOURAGING LOWER-DEBT LiFESTYLES}

A third approach to addressing future debt would encourage the pursuit of life plans that are less likely to require debt financing. This approach could be consistent with remedying disadvantage as well as with stabilizing expectations.

What strategies would discourage life plans that require extensive debt financing and encourage alternative and fulfilling plans of life? Elizabeth Warren has argued that families should scale down their fixed costs-should consider purchasing cheaper houses and avoiding automobile loans and private school tuition-to ensure that their economic plans are sustainable. ${ }^{41}$ Juliet Schor has similarly suggested that households voluntarily "downshift" by adopting plans of life that require less material consumption and less ownership of assets; such life plans will also be less dependent on access to debt financing. ${ }^{42}$ However, even these alternative life plans will require some external support. Accordingly, society might also work to support broadly accessible social goods-such as

\footnotetext{
${ }^{39}$ Wertheimer, "Book review," p. 544. The potential advantages of regulations on unequal trades are further explored in Efthymios Athanasiou, Alex John London, and Kevin J. S. Zollman, "Dignity and the value of rejecting profitable but insulting offers," Mind, 124 (2015), 409-48, at pp. 442-3.

${ }^{40}$ See Wertheimer, "Book review," p. 545; see also Hudon and Ashta, "Fairness and microcredit interest rates," p. 287.

${ }^{41}$ Warren and Tyagi, The Two-Income Trap, pp. 164-5.

${ }^{42}$ Juliet Schor, The Overspent American (New York: HarperCollins, 1999), pp. 22-3.
} 
publicly accessible parks and libraries-that can serve as building blocks for life plans that do not depend on targeted support of one's individual economic status.

Meanwhile, when considering what a fulfilling and low-debt plan of life might look like, a Rousseauian insight represents one useful starting point: forms of status that require only recognition as an equal citizen are self-sustaining in a way that those depending on interpersonal or intrapersonal resource comparisons are not. ${ }^{43}$ Religion and spirituality might provide another source of meaningful life plans that require few material resources. A recent article examines research on lifestyles of "voluntary simplicity," which aim to limit consumer spending and to seek meaning through activities other than consumption, and finds that intrinsic religiosity (the practice of religion for its own sake) is correlated with voluntary simplicity, as are secular values such as environmental and community concern. ${ }^{44}$ Elements of many religious traditions explicitly advocate complete detachment from material possessions and worldly desires. ${ }^{45}$ In contrast, religious practice that involves outward ceremony or display can lead to increased debt-religious ceremonies, for instance, are reported to represent a major expense for rural South Asian households. ${ }^{46}$

\section{CONCLUSION}

I agree wholeheartedly with Lisa Herzog that "debt relations are too important for the well-being of individuals and families, and create too much risk for them and for societies as a whole, to leave them to the free play of market forces," and that debts "need to be a focus of public policy, and they need to be considered not only from a perspective of efficiency, but also from a perspective of justice." ${ }^{47}$ In this article, I have offered two frameworks for thinking about household debt relief, bearing in mind that efficiency may itself be an aspect of distributive justice. These frameworks focus on the remediation of disadvantage and on the stabilization of expectations. I have then applied these frameworks to real-world proposals for addressing existing and future household debt.

The adoption of any of these real-world proposals, of course, will involve the challenges of transitioning between regulatory regimes. From the perspective of stabilizing expectations, transitions are challenging because people frequently do not expect them and perceive them as disruptive. For instance, both creditors and

${ }^{43}$ Joshua Cohen, Rousseau: A Free Community of Equals (Oxford: Oxford University Press, 2010), pp. 117, 121; Frederick Neuhouser, Rousseau's Theodicy of Self-Love (Oxford: Oxford University Press, 2008), pp. 62-3.

${ }^{44}$ Rafi M. M. I. Chowdhury, "Religiosity and voluntary simplicity: the mediating role of spiritual well-being," Journal of Business Ethics (forthcoming).

${ }^{45}$ Examples from Christianity and Hinduism are discussed in Sarvepalli Radhakrishnan, "The ethics of the Bhagavadgita and Kant," International Journal of Ethics, 21 (1911), 465-75, at p. 475.

${ }^{46}$ Isabelle Guerin, Marc Roesch, Santosh Kumar, et al., "Microfinance and the dynamics of financial vulnerability: lessons from rural South India," Rural Microfinance and Employment Project working paper 2009-5, <http://citeseerx.ist.psu.edu/viewdoc/download?doi=10.1.1.906.4384\&rep $=$ rep1\&type $=$ pdf $>$.

${ }^{47}$ Herzog, "What could be wrong with a mortgage?", p. 431. 
debtors may perceive changes in interest rates or the provision of new debt relief mechanisms as unexpected. However, providing advance warning can help to reconcile regulatory change with the stabilization of expectations. It is not reasonable for people to, for instance, expect that interest rates will remain constant over time, given public consciousness about the possibility of shifting interest rates. ${ }^{48}$ Meanwhile, from the perspective of remedying disadvantage, transitions away from a highly non-ideal arrangement are more attractive, because people lack legitimate claims to the advantages they have won under these arrangements. However, even this perspective must deal with the practical and political-rather than normative-challenges of transitions between different policy arrangements. ${ }^{49}$

Though I am more sympathetic to approaching debt relief through the lens of remedying disadvantage than through that of stabilizing expectations, both approaches share an important feature. Rather than regarding household debt relief as valuable in itself, or regarding justice with respect to debts as separate from justice in general, both regard household debt relief as one among many instrumentally valuable policies. They both see household debt relief as a goal we should pursue insofar as it better realizes justice, and should integrate into a menu of other policies that realize justice. Even if approaches that place debt relief front and center prove to be politically effective or useful in coalition building, thoughtful reflection demonstrates that debt relief, even when justified, is ultimately a means to more fundamental goals. While policies for the relief and prevention of burdensome household debts are more than mere "bandaids," 50 they are not ends in themselves, nor are they governed by separate rules of "debt justice." Rather, they are an important part, but only a part, of the larger task of achieving justice.

\footnotetext{
${ }^{48}$ For more on this point, see the discussion of when expectations are reasonable in Goodin, "Stabilizing expectations," pp. 551-3.

${ }^{49}$ Persad, "Downward mobility and Rawlsian justice," sec. 3.

${ }^{50}$ Here I again agree with Herzog, "What could be wrong with a mortgage?", p. 426, who observes that reforms to private debt markets represent "a lever in the fight against oppression-not the only lever, and maybe not the most important one, but one that deserves attention."
} 